\title{
Nowatorstwo modernistycznej prozy Alfreda Döblina na przykładzie opowiadania Die Ermordung einer Butterblume (Mord na kwiecie kaczeńca)
}

\section{Wstęp}

Alfred Döblin (1878-1957), niemiecki dramaturg i eseista, z zawodu lekarz psychiatra, to czołowa postać niemieckiego ekspresjonizmu. W jego wizjonerskiej twórczości wyraża się estetyczny nonkonformizm. Zafascynowany filozofią Kanta, Nietzschego i Schopenhauera, pisarz powracał nieustannie w swoich utworach do problemu siły i słabości, przemocy i ofiary, buntu i poświęcenia ${ }^{1}$. Jego opowiadanie Die Ermordung einer Butterblume, pochodzące z tomu pt. Die Ermordung einer Butterblume und andere Erzählungen (1910-1911), uznaje się za kluczowy tekst prozatorski wczesnego ekspresjonizmu niemieckiego. Opisana jest w nim dekonstrukcja indywiduum przez naturę, której wyższość musi uznać człowiek żyjący w wielkim mieście, człowiek wyobcowany i z natury „wykorzeniony”. Każda próba powrotu do pierwotnego miejsca życia skazana jest na porażkę. Posługując się dualistycznym (realnym i surrealistycznym) obrazem świata, Döblin w nowatorski sposób kreuje postać protagonisty utworu - Michaela Fischera, przedstawiając czytelnikowi jego świat doznań zewnętrznych i wewnętrznych przeżyć oraz traktując jego przypadek jako studium psychozy.

* Dr, beatakol@poczta.onet.pl, Uniwersytet Pedagogiczny im. KEN w Krakowie, Wydział Filologiczny, Instytut Neofilologii, Katedra Literatury Niemieckojęzycznej, ul. Studencka 5, 31-116 Kraków.

${ }^{1}$ Por. S. Lichański, Twórczość Alfreda Döblina; http://sedina.pl/wordpress/index.php/2007/01 /18/twrczo-alfreda-dblina/ [dostęp: 24.05.2015]. 


\section{Ekspresjonizm w Niemczech - zarys epoki}

Ekspresjonizm rozwinął się epoce przesiąkniętej wojennym okrucieństwem. Jako ruch artystyczny powstał w dźwigających się po wojennej porażce Niemczech w pierwszym trzydziestoleciu XX wieku, ale już wcześniej stanowił hasła grup awangardowych; w 1911 roku Kurt Hiller ogłosił: „Jesteśmy ekspresjonistami”, nazywając w 1913 roku ekspresjonizm stylem powstałym z uratowanych jakości epok wcześniejszych²; w 1917 roku Kasimir Edschmied zdefiniował go natomiast jako kierunek wizjonerski, odmienny wobec fotograficznego naturalizmu ${ }^{3}$. W programowym Der Sturm pod redakcją Herwartha Waldena oraz Die Aktion wydawanym przez Franza Pfemferta usiłowano sformułować ekspresjonistyczny manifest i ustalić zasady, jakimi powinien kierować się artysta początku XX wieku. Próby ustabilizowania sytuacji w powojennej Europie podczas konferencji paryskiej wywoływały jednakże w Niemczech niepokój o przyszłość społeczeństwa, o której mieli decydować wojenni przeciwnicy. Do charakterystycznego dla tego czasu konfliktu pokoleniowego pomiędzy generacją ojców i synów przyczyniła się przede wszystkim „,negacja dorobku generacji ojców, pokolenia, które doprowadziło do śmierci milionów [i] pozwoliło, aby o losie synów decydowali wrogowie. Spektrum wartości uległo diametralnej transformacji, ekspresjonizm negował to, co przez wiek XVIII i XIX było oczywistością" ${ }^{\text {. }}$.

Ideologiczne podwaliny ekspresjonizmu to przede wszystkim myśl wielkich filozofów niemieckich: metafizyka Immanuela Kanta oraz fenomenologiczne spojrzenie na świat Edwarda Husserla, który negował tezy a prori i założenia postrzegania rzeczywistości takiej, jaka jest. Widoczne są również wpływy filozofii Friedricha Nietzschego, zakładającego istnienie w człowieku dzikiego i nieokiełznanego żywiołu, oraz odwołania do teorii Sigmunda Freuda i jego tajemniczości ludzkiej egzystencji ${ }^{5}$. To właśnie maksymy Zaratustry Nietschego i rozważania $O$ marzeniu sennym (Über den Traum, 1900) współkształtowały ekspresjonistyczną utopię „,nowego człowieka", aktywnego intelektualisty zaangażowanego w politykę .

Ekspresjonizm w Niemczech, a dokładnie w utworzonej z ich terenów Republice Weimarskiej, to okres intensywnego rozwoju literackiego. W literaturze ekspresjonistycznej obok dramatów (B. Brecht, F. Wedekind, G. Kaiser) oraz li-

${ }^{2}$ Por. K. Hiller, Expressionismus, w: Expressionismus. Manifeste und Dokumente zur deutschen Literatur 1910-1920. Mit Einleitungen und Kommentaren, red. T. Anz, M. Stark, Metzler, Stuttgart 1982, s. 37.

${ }^{3}$ Por. Cz. Karolak, W. Kunicki, H. Orłowski, Dzieje kultury niemieckiej, Wydawnictwo Naukowe PWN, Warszawa 2007, s. 388.

${ }^{4}$ F. Jalowski-Fidel, Krótka historia niemieckiego ekspresjonizmu filmowego http://film.org.pl/ prace/ekspresjonizm.html [dostęp: 24.05.2015].

${ }^{5}$ Por. tamże.

${ }^{6}$ Por. Cz. Karolak, W. Kunicki, H. Orłowski, dz. cyt., s. 388-389. 
ryki (G. Benn, G. Trakl, E. Stadler) dominują krótkie formy prozatorskie, jak nowele i opowiadania (A. Döblin, F. Kafka, G. Heym). Utwór zakłada odejście od naturalistycznej koncepcji świata przedstawionego i staje się wyrazem skrajnego subiektywizmu w odczuciach, co w warstwie leksykalnej prowadzi do ucieczki od piękna formy, a co za tym idzie - do barbaryzacji języka ${ }^{7}$ estetyki brzydoty. Mimo że proza ekspresjonistyczna nie dorównywała ilościowo ani emfatycznej poezji, ani analitycznym dramatom, to również stawiała w centrum zdepersonalizowaną jednostkę ludzką, podważając racjonalność jako taką oraz ukazując proces rozpadu subiektywnego ja: „Man muß das Ich in der Literatur zerstören! ${ }^{8}$ („Trzeba zniszczyć Ja w literaturze!” - tłum. własne). Za najważniejsze dokonanie ekspresjonizmu niemieckiego uważa się „okrycie deficytów i zagrożeń przełomu wieków: utraty potrzeb metafizycznych przez modernę, stopnia i zasięgu przenikania nowoczesnej techniki w życie człowieka, zastygłych w wartościach etycznych i estetycznych społeczności wilhelmińskiej"”. W tej atmosferze niemieccy ekspresjoniści stanowili ,awangardową orientację protestującą rozpoznawalną dzięki wyrażaniu sprzeczności między industrializacją a zastygłą tradycjonalnością, wymarszem ku modernie a jej polityczną mglistością?"10.

\section{Opowiadanie Ermordung einer Butterblume (Mord na kwiecie kaczeńca) - zarys treści}

Protagonistą opowiadania Die Ermordung einer Butterblume (Mord na kwiecie kaczeńca) jest poważny, elegancko ubrany pan Michael Fischer, którego poznajemy podczas - niewinnego początkowo - wieczornego spaceru po lesie. W dość idyllicznej scenerii wiosennej natury bohater nieoczekiwanie wpada w szał, widząc swoją laskę spacerową oblepioną listowiem. Nie mogąc pozbyć się tej roślinności, wyprowadzony z równowagi bohater zaczyna okładać laską wszystkie rośliny będące w zasięgu jego ręki:

[...] stał przez moment oniemiały. Sztywny kapelusz zsunął mu się na kark. Zmierzył wzrokiem wybujałe kwiaty, a potem, wzniósłszy laskę, rzucił się na nie, i z twarzą nabiegłą krwią, zaczął siec nieme rośliny. Ciosy świstały w prawo i lewo. Łodygi i liście fruwały aż na drugą stronę drogi ${ }^{11}$.

\footnotetext{
${ }^{7}$ Por. F. Jalowski-Fidel, dz. cyt.

${ }^{8}$ F.T. Marinetti, Die futuristische Literatur. Technisches Manifest, w: Expressionismus..., s. 606.

${ }^{9}$ Cz. Karolak, W. Kunicki, H. Orłowski, dz. cyt., s. 389.

${ }^{10}$ Tamże, s. 389.

${ }^{11}$ A. Döblin, Mord na kwiecie kaczeńca, przeł. M. Świętek, w: Gabinet figur woskowych, red. H. Orłowski, Wydawnictwo Poznańskie, 1980, s. 104.
} 
Dawszy upust swoim emocjom, kontynuuje spacer, rozglądając się jednakże uważnie, czy przypadkiem ktoś nie był świadkiem jego napadu wściekłości. Również kwiaty, które zniszczył, nie dają mu spokoju - Fischer zaczyna bowiem myśleć o swoim czynie jako o morderstwie na kwiecie kaczeńca, malując w swojej wyobraźni dokładny scenariusz czynu - odciętą głowę kwiatu w trawie oraz sączącą się z łodygi białą krew rośliny:

I nagle, omiótłszy wzrokiem brzeg drogi, pan Michael Fischer zobaczył, jak jakaś przysadkowata postać, on sam schodząc z murawy, rzuca się na kwiaty i jednemu kaczeńcowi odcina zręcznie głowę. Całkiem namacalnie rozegrało się przed nim to, co wydarzyło się przedtem na cienistej drodze. Ten kwiat, tam, był dokładnie jotę w jotę taki sam jak inne. Ale właśnie tej jeden przyciągnął jego spojrzenie, jego rękę, jego laskę. Podniosło się ramię, kij świsnął, ciach i głowa spadła. Przekoziołkowała się w powietrzu, zniknęła w trawie. Dziko zabiło serce kupca. Ciężko spadła głowa rośliny i zaczęła wkręcać się w trawę głębiej, coraz głębiej, poprzez powierzchnię murawy, w ziemię. Teraz zaczęła pędzić dalej, w głąb ziemi, tak że nie zdołałaby zatrzymać jej już żadna ręka ${ }^{12}$.

Fischer wyobraża sobie również, że odcięta głowa kaczeńca zaczyna gnić, a cała zgnilizna płynie w jego kierunku:

W pobliżu w trawie gnije głowa. Depczą po niej, rozmywa się w deszczu, rozkłada się. Robi się z niej żółta śmierdząca miazga, zielonkawa, mieniąca się żółtawo, szlamowata jak wymiociny. I to coś podnosi się żywe na niego, właśnie na pana Michaela, chce go zalać, opływa chlupoczącym strumieniem jego ciało, bryzga w nos. On podskakuje w górę, teraz już tylko wspina się na palcach ${ }^{13}$.

Bohater zaczyna uciekać, ma wrażenie, że nogi niosą go same, jak najdalej od miejsca morderstwa. Nagle wpada na pomysł urządzenia pogrzebu dla kaczeńca. Wraca na miejsce kaźni i prosi pozostałe kwiaty o pomoc przy szukaniu tego, który zginął z jego ręki:

Gdzie jest to miejsce? Musi to miejsce znaleźć. Gdybyż tylko mógł przywołać ten kwiat. Nie wiedział nawet, jak on się nazywał. Ellen? Może było mu na imię Ellen, tak, na pewno Ellen. Szeptał w trawę, pochylał się, nawet trącał kwiaty ręką.

„Jest tu Ellen? Wy, tam, no co? Ona jest ranna, w głowę, nieco poniżej głowy. Może jeszcze o tym nie wiecie. Chcę jej pomóc; jestem lekarzem, samarytaninem. No, gdzie ona leży? Możecie mi zaufać, zapewniam was."

\footnotetext{
12 Tamże, s. 105

13 Tamże, s. 107.
} 
Lecz w jaki sposób miał ją rozpoznać, on, który ją złamał? Może to właśnie ją chwycił w rękę, może ona tu w pobliżu niego wydawała ostatnie tchnienie.

Do tego nie wolno dopuścić.

Wrzeszczał: „Wydajcie ją. Nie unieszczęśliwiajcie mnie, wy, psy. Jestem samarytaninem. Nie rozumiecie po niemiecku?"14.

Po daremnej próbie odnalezienia ofiary swojej wściekłości, Fischer, miotany sprzecznymi emocjami, z przerażeniem odkrywa, że leśna droga zdaje się coraz bardziej zwężać, tworząc pułapkę na mordercę:

Ona umarła. $Z$ jego ręki.

Westchnął i potarł w zamyśleniu czoło.

Opadną go ze wszystkich stron. Niechby nawet, nie obchodzi go już nic więcej. [...] Oni nie mieli prawa go karać, sami są niegodziwcami. Tak, zabił kwiat, i to ich nic nie powinno obchodzić, miał do tego swoje prawo i obstaje przy tym przeciwko nim wszystkim. Miał swoje prawo zabijać kwiaty, i nie czuje się zobowiązany uzasadniać tego bliżej. [...]

Stanął; jego oczy patrzyły gniewnie w głęboką czerń świerków. Wargi były napęczniałe od krwi. Potem ruszył pędem przed siebie.

Chyba musi to w lesie złożyć kondolencje siostrom zmarłej. Da do zrozumienia, że to nieszczęście stało się prawie bez jego udziału, wspomni o pożałowania godnym wyczerpaniu, w jakie popadł. I o upale. A tak w gruncie rzeczy to wszystkie kaczeńce razem wzięte są mu obojętne. [...]

Ogarnia go jednak przerażenie, gdy spostrzega, jak z jakiegoś pnia, którego dotknął, wycieka okrągła, jasnoblada kropla żywicy; drzewo płacze. W ciemności, złorzecząc na ścieżkę, spostrzega wkrótce, że droga zwęża się jakoś dziwnie, jakby las chciał go zwabić w pułapkę. Drzewa zbierają się na sąd ${ }^{15}$.

Fischer rzuca się do ucieczki i, nie bacząc na gęstwinę lasu, dociera po zmro$\mathrm{ku}$ do domu w podartym garniturze i z krwawiącym czołem. Jego życie nabiera surrealistycznego kształtu: jego myśli krążą permanentnie wokół Ellen. To jej Fischer składa w ofierze jedzenie i picie, dla niej zakłada konto oszczędnościowe. Wraca nawet do lasu, odnajduje rzekomą córkę Ellen i zabiera ze sobą do domu, licząc $\mathrm{w}$ ten sposób na zadośćuczynienie za swoją zbrodnię. Kwiat posadzony w złotej donicy pełni rolę rekompensaty i uspokaja wyrzuty sumienia bohatera. Kiedy jednak pewnego dnia sprzątaczka wyrzuca roślinę wraz z niechcący rozbitą doniczką, Fischera opanowuje ogromna radość i poczucie ulgi - tym razem to nie on dopuścił się morderstwa:

\footnotetext{
14 Tamże, s. 109.

15 Tamże, s. 110-111.
} 
Gdy któregoś dnia wieczorem wrócił spacerkiem, zadowolony, ze swojego kantoru do mieszkania, jego gospodyni zaraz od drzwi oświadczyła mu jakby nigdy nic, że przy sprzątaniu stoliczek się przewrócił i naczynie się zbiło. I że ona to podłe zielsko śmietnikowe kazała wyrzucić razem ze wszystkim skorupami do wiadra na śmieci. Rzeczowy, lekko pogardliwy ton, którym ta osoba informowała o zdarzeniu, dawał do zrozumienia, że to co zaszło, sprawiło jej zadowolenie.

I wtedy przysadkowaty pan Michael zatrzasnął drzwiami, klasnął w swoje krótkie rączki, zapiszczał głośno ze szczęścia i objąwszy w biodrach zaskoczoną kobietę, podniósł ja w górę tak wysoko, jak na to pozwoliły siły i odległość do sufitu. Potem, niczym pies merdający ogonem wybiegł przez korytarz do swojej sypialni, z płonącymi oczami, podniecony do najwyższego stopnia; głośno dyszał, tupał nogami, jego wargi drżały.

Nikt nie mógł mu nic zarzucić; on nawet w najskrytszych myślach nie życzyłby kwiatu śmierci, nawet najmniejszym odruchem jednej myśli nie przyczynił się do tego. Ta stara, świekra, może teraz przeklinać i mówić co jej się żywnie podoba. On teraz nie ma już z nią nic wspólnego. Są rozwiedzeni. Wreszcie pozbył się już tego całego pokrewieństwa z kaczeńcami. Prawo i szczęście były po jego stronie ${ }^{16}$.

Wolny i pozbawiony raz na zawsze wszelkich wyrzutów sumienia, bohater udaje się na spacer do lasu: „Może mordować, ile tylko zechce. Gwiżdże na te wszystkie kaczeńce" ${ }^{\prime 17}$.

\subsection{Pan Michael Fischer jako protagonista utworu - dualizm postaci}

Nie można oprzeć się wrażeniu, że opisane w opowiadaniu groteskowe zdarzenie idealnie odzwierciedla sytuację kafkowską: mamy do czynienia bowiem z ekscentrycznym mężczyzną, w umyśle którego absurdalny czyn urasta do rangi grzechu śmiertelnego, powodując zaburzenia postrzegania otaczającej rzeczywistości w sposób zdroworozsądkowy Niejasne pozostają zarówno motywy działania Fischera, wskutek których dokonał się mord na roślinie, jak i jego późniejsza obsesja potrzeby zadośćuczynienia, wynikająca jednakże bardziej ze strachu przed byciem oskarżonym o zbrodnię niż powodowana wyrzutami sumienia.

Kreacja głównej postaci jest od początku utworu dualistyczna: pan Michael Fischer to osobowość autorytarna, której działanie oparte jest na sile i przemocy, zarówno w życiu prywatnym, jak i na polu zawodowym. W absurdalny sposób szykanuje on podległych mu współpracowników, każąc im między innymi ła-

\footnotetext{
16 Tamże, s. 115.

17 Tamże, s. 116.
} 
pać latające w biurze muchy i sortować je według wielkości. Za nieprecyzyjne wykonanie zadania wymierzane są kary cielesne. Mimo epatowania władczym zachowaniem, jego słabość zdradzają reakcje po zabójstwie kaczeńca: zachwianie pewności siebie, wyolbrzymione do skraju możliwości wyrzuty sumienia oraz mania prześladowczej. Te dwie odmienne natury Fischera zdają się jednakże współegzystować i logicznie się uzupełniać: być może w skutek kompleksu niższości protagonista poniża współpracowników i na wszelkie przejawy niesubordynacji reaguje z niewyobrażalną i niczym nie wytłumaczalną agresją? ${ }^{18}$

Fischer gubi się w otaczającym go świecie: próbując znaleźć usprawiedliwienie swoich czynów (zmęczenie pracą, upał), uzurpuje sobie prawo zabicia kwiatu - przecież w gruncie rzeczy kwiaty to coś i jemu, i innym obojętnego. Fischer konfrontuje się permanentnie z myślami o nieżyjącym kaczeńcu, swoje odczucia traktuje tak samo jak poniżanych współpracowników - chce je ujarzmić, tak aby nie zagrażały jego poczuciu własnej wartości. Zastosowany tu przez Döblina motyw demontażu człowieka jako indywiduum odzwierciedla typowy dla literatury ekspresjonizmu niemieckiego konflikt świata natury i rzeczywistości mieszczańskiej, będący walką pomiędzy pragnieniami jednostki, jej władczą naturą, mającą korzenie w mentalności społeczeństwa wilhelmińskiego, a anonimowymi siłami współczesnych metropolii i społeczeństwa - walką, w której jednostka ludzka jest skazana na porażkę w świecie moderny. Człowiek nowoczesnych metropolii jest jednostką wyobcowaną i wykorzenioną ze swoich naturalnych miejsc pierwotnych ${ }^{19}$.

Personifikacja kaczeńca to Döblinowski sposób na literacki opis funkcji ludzkiego sumienia, rozpiętego u Fischera pomiędzy kategoriami wyparcia a zadośćuczynienia:

Pan Michael odruchowo wsadził kapelusz na spoconą głowę, przycisnął ręce z laską do piersi. „Co się stało? - spytał po chwili. - Nie jestem pijany. Niemożliwe, żeby głowa się zapadła, ona musi tu leżeć, musi leżeć tu gdzieś w trawie. Jestem przekonany, że ona teraz spokojnie leży w trawie. A krew... Nie przypominam sobie tego kwiatka, nie wiem absolutnie o niczym."

Zdziwiony, zmieszany nie dowierzał sam sobie. Zastygł cały w tym niesamowitym wzburzeniu, wstrząśnięty myślał o kwiatku, o uciętej głowie, o krwawiącej łodydze. Wciąż jeszcze skakał przez ten szlamowaty potok. No gdyby go kto tak widział, ktoś z jego przyjaciół od interesów lub jakaś dama...

Pan Michael napuszył się, prawą ręką ścisnął kurczowo laskę. Spojrzał na swoje ubranie i upewnił się co do swojej postawy. A z tymi nieposłusznymi myślami już on sobie poradzi: zapanować nad sobą. Tym brakiem posłuszeństwa już on, szef, pokieruje

${ }^{18}$ Por. S. Leichsenring, Alfred Döblin: Die Ermordung einer Butterblume. Inhaltsangabe und Interpretation, http://www.leixoletti.de/interpretationen/dieermordungeinerbutterblume.htm [dostęp: 24.05.2015].

${ }^{19}$ Por. tamże. 
energicznie. Tej tu czeredzie trzeba z całą stanowczością stawić odpór: „Czym można służyć? W mojej firmie takie postępowanie nie jest w zwyczaju. Służący, precz z tym łobuzem". Stojąc wygrażał przy tym laską dokoła. Przybrał odpychający, zimny wyraz twarzy, no, niech no tylko ${ }^{20}$.

Podejmowane przez protagonistę groteskowe próby odpokutowania za zbrodnię (chęć urządzenia pogrzebu dla Ellen, ofiary w postaci jedzenia i picia, poczynione dla kaczeńca oszczędności pieniężne czy też opieka nad domniemaną córką rośliny) podkreślają jednakże jedynie utratę kontaktu z otaczającą go rzeczywistością:

Pokutował, pokutował swą tajemną winę. Odprawiał nabożeństwo do kaczeńca; on, spokojny kupiec, zaczął twierdzić, że każdy człowiek ma swoją własną religię, że należy mieć indywidualny stosunek do jakiegoś nieogarnionego Boga. Istnieją rzeczy, które nie każdy obejmie rozumem. Na jego twarzy poważnego małpiątka pojawił się rys cierpienia; zgubił tuszę, oczy zapadły się głęboko. Kwiat wnikał w jego poczynania niczym sumienie, surowo, w największe sprawy i w najmniejsze, codzienne ${ }^{21}$.

Ellen staje się sumieniem Fischera, niewygodnym narzędziem doprowadzającym go prawie do psychozy. Nieoczekiwany ratunek przychodzi w momencie skrajnego wyczerpania psychicznego protagonisty i okazuje się być wręcz banalnym rozwiązaniem, jakim jest przeniesienie odpowiedzialności i wyrzutów sumienia na gosposię, która nieświadoma pozbywa się rozbitej doniczki wraz z jej zawartością. W koncepcji protagonisty zadziwia więc ogromna łatwość uwikłania się w swoiste stadium psychozy oraz szybkość uwolnienia się od dręczących strachów. Poraża również relatywizm moralny Fischera, według którego czyn sprzątaczki wymazuje jego winę.

\section{Zakończenie}

Surrealistyczne, kafkowskie niemal opowiadanie Döblina to bardzo plastyczny i oryginalny jak na ówczesny czas obraz. Krótki fragment życia Fischera zadziwia, napawa strachem, czasami wstrętem, ale miejscami również śmieszy. Literacko utwór wydaje się być interesujący ze względu na wieloznaczność interpretacji. Tekst można odczytać jako realistyczny obraz postrzegania świata przez osobę chorą umysłowo (za taką analizą przemawiałyby prowadzona nar-

\footnotetext{
${ }^{20}$ A. Döblin, dz. cyt., s. 106.

${ }^{21}$ Tamże, s. 122-123.
} 
racja, w której narrator nie komentuje, nie podważa a tylko relacjonuje, oraz biografia autora, który swego czasu był praktykującym psychiatrą). Jednakże dualistyczna koncepcja protagonisty i niezwykle intensywnie opisane przeżycia bohatera pozwalałby interpretować tekst w kategoriach literatury fantastycznej, gdyż tak naprawdę utwór dostarcza informacji sugerujących zarówno, że opisane wydarzenia mogły zajść realnie, jak też, że tylko śniły się głównemu bohaterowi. O dialektycznym (realistyczno-fantastycznym) charakterze utworu świadczyć może chociażby wprowadzona prze autora wielostopniowa narracja, powodująca u czytelnika niepewność co do zaistniałych wydarzeń: narrator nie tylko relacjonuje zdarzenia z życia protagonisty, lecz wielokrotnie się z nim utożsamia, dając czytelnikowi możliwość kompletnego oglądu sytuacji dotyczących zachowania i sposobu myślenia Michaela Fischera ${ }^{22}$.

Bohater opowiadania, jak czytamy w posłowiu do Gabinetu figur woskowych (1980) - antologii wydanej pod redakcją Huberta Orłowskiego i zawierającej jedyne znane mi tłumaczenie utworu Döblina autorstwa Marii Świętek z 1962 roku - jest przedstawicielem ,innych”, a więc schizofreników i paranoików, którzy uruchamiają zepchnięte w podświadomość mechanizmy agresji. Ich ucieczka przed rzeczywistością $\mathrm{w}$ świat paranoicznych urojeń może być tak samo niebezpieczna jak zbiorowa agresja: dla twórców tych urojeń oraz ich otoczenia. W kontekście praktyki stygmatyzacji społeczno-politycznej ,innych” utwór Döblina można odczytywać jako antycypację zagłady zgotowanej ludzkości przez Trzecią Rzeszę ${ }^{23}$. We współczesnej recenzji owej antologii ktoś z internautów trafnie ujął: „Zdolność ludzkiego umysłu do projekcji własnych fobii zdaje się fascynować, a zarazem przerażać literatów, którzy chętnie korzystali z motywu obłędu, zawsze pozostawiając sąd o racjonalności zaistniałych zdarzeń niedopowiedzianym"24. Może dlatego opowiadanie Döblina, będące dobrze zbudowanym utworem grozy, pozostaje wciąż aktualne, fascynujące oraz wyraźnie ukazujące, w jaki sposób rzeczywistość wpływa na fantazję i jak inspiruje artystę.

\section{Bibliografia}

Döblin Alfred, Mord na kwiecie kaczeńca, przeł. M. Świętek w: Gabinet figur woskowych, red. H. Orłowski,Wydawnictwo Poznańskie, 1980, s. 104-116.

Hiller Kurt, Expressionismus, w: Expressionismus. Manifeste und Dokumente zur deutschen Literatur 1910-1920. Mit Einleitungen und Kommentaren, red. T. Anz, M. Stark, Metzler, Stuttgart 1982, s. 37.

${ }^{22}$ Por. H. Kleinholdermann, Kommentar zu Alfred Döblins Erzählung „,Die Ermordung einer Butterblume“, http://www.literatur-kommentare-online.de/doeblin.html\#VI [dostęp: 24.05.2015].

${ }^{23}$ Por. H. Orłowski, Posłowie, w: Gabinet figur..., s. 362-363.

24 O. Piech, recenzja: Gabinet figur woskowych. Opowieści niesamowite, http://horror.com.pl/ books/recka.php?id=524 [dostęp: 24.05.2015]. 
Jalowski-Fidel, Filip, Krótka historia niemieckiego ekspresjonizmu filmowego, http://film.org.pl/ prace/ekspresjonizm.html [dostęp: 22. 04. 2015].

Karolak Czesław, Kunicki Wojciech, Orłowski, Hubert, Dzieje kultury niemieckiej, Wydawnictwo Naukowe PWN, Warszawa 2007.

Kleinholdermann, Hans, Kommentar zu Alfred Döblins Erzählung „,Die Ermordung einer Butterblume“, http://www.literatur-kommentare-online.de/doeblin.html\#VI [dostęp: 22.04.2015].

Leichsenring Stefan, Alfred Döblin: Die Ermordung einer Butterblume. Inhaltsangabe und Interpretation, http://www.leixoletti.de/interpretationen/dieermordungeinerbutterblume.htm [dostęp: 22.04.2015].

Lichański, Stefan, Twórczość Alfreda Döblina, http://sedina.pl/wordpress/index.php/2007/01/18/ twrczo-alfreda-dblina/ [dostęp: 22.04.2015].

Marinetti Filippo Tommaso, Die futuristische Literatur. Technisches Manifest, w: Expressionismus. Manifeste und Dokumente zur deutschen Literatur 1910-1920. Mit Einleitungen und Kommentaren, red. T. Anz, M. Stark, Metzler, Stuttgart 1982, s. 604-609.

Piech, Olga, recenzja: Gabinet figur woskowych. Opowieści niesamowite, http://horror.com.pl/ books/recka.php?id=524 [dostęp: 22.04.2015].

Beata Kołodziejczyk-Mróz

The novelty of the modernist prose by Alfred Döblin on the example of the story Die Ermordung einer Butterblume (The Murder of a Buttercup)

\section{(Summary)}

Alfred Döblin's short story Die Ermordung einer Butterblume (The Murder of a Buttercup), from the collection Die Ermordung einer Butterblume und andere Erzählungen (1910-1911), is considered a key prose text of early German expressionism. It describes the deconstruction of an individual by nature, the superiority of which must be recognised by a man living in a big city, alienated and "uprooted" from nature. Any attempt to return to the original place of life is bound to fail. Employing a dual (real and surreal) image of the world, Döblin creates an innovative portrayal of the protagonist - Michael Fischer, presenting the reader with the world of his internal and external experience and treating his case as a study of psychosis.

Słowa klucze: ekspresjonizm niemiecki; dualistyczny obraz świata; studium psychozy; groza Keywords: German Expressionism; dualistic view of the world; study of psychosis; terror 